\title{
Turkish Teachers' Attitudes Towards Distance Learning During the Covid-19 Pandemic
}

\author{
Sedat Karagul ${ }^{1} \&$ Erhan $\operatorname{Sen}^{2}$ \\ ${ }^{1}$ Faculty of Education, Istanbul 29 Mayis University, Istanbul, Turkey \\ ${ }^{2}$ Faculty of Education, Van Yuzuncu Yil University, Van, Turkey \\ Correspondence: Sedat Karagul, Faculty of Education, Istanbul 29 Mayis University, Istanbul, Turkey. \\ Received: June 12, $2021 \quad$ Accepted: July 20, $2021 \quad$ Online Published: September 18, 2021 \\ doi:10.5539/ies.v14n10p53 \\ URL: https://doi.org/10.5539/ies.v14n10p53
}

\begin{abstract}
All schools in Turkey have switched to distance learning since the onset of the pandemic. This paper investigated Turkish teachers' attitudes towards distance learning based on different variables. This study adopted a mixed research design employing both quantitative and qualitative data collection methods. The sample consisted of 292 Turkish teachers. The qualitative stage involved 292 Turkish teachers, while the qualitative stage involved ten Turkish teachers. Data were collected using a demographic characteristics questionnaire and the Distance Learning Attitude Scale (DLAS) developed by Ağır (2007). Frequency, percentage, arithmetic mean, and standard deviation were used for analysis. A t-test was used to determine whether participants' attitudes towards distance learning differed by "gender" and "degree." An ANOVA was used to determine whether participants' attitudes towards distance learning differed by "work experience" and "knowledge and experience in distance learning." The Mann-Whitney U test was used to determine whether participants' attitudes towards distance learning differed by "school type." A Scheffe's Test was used to make posthoc comparisons to determine the source of significant differences. Qualitative data were collected through focus group interviews using a semi-structured interview form $(\mathrm{n}=10)$. The qualitative data were analyzed using content analysis. The results showed that participants had positive attitudes towards some aspects of distance learning, whereas they had negative attitudes towards others. Their DLAS scores significantly differed by "school type," "work experience," and "knowledge and experience in distance learning" but not by "gender" and "degree."
\end{abstract}

Keywords: Covid-19, distance learning, Turkish teacher, attitude, mixed-method

\section{Introduction}

Current advances in technology and communication and changes in socioeconomic conditions have paved the way for novel education models. One of those models is distance learning, which has become prevalent due to advances in computer technology and the endless possibilities of the Internet. Demir (2014) maintains that we live in an information age, which provides numerous educational opportunities. One of those opportunities is distance learning, an alternative way to diversify learning methods to meet the requirements of being a network society in this information age.

Distance learning has been an option to meet various needs and requirements. For example, schools have been caught understaffed in the face of the growing number of students enrolling over the past few decades. Besides, new demands have emerged in the education system because people have become more mobile and geographically more separated. Therefore, they would like to have access to a quality education whenever and wherever they want. Another reason is that schools have become more interested in training their staff in a more cost- and time-effective manner (Karakaya \& Aksoy, 2005). Distance learning is an indispensable part of today's world due to the COVID-19 pandemic.

Novel Coronavirus disease (COVID-19) broke out at the end of 2019 and has taken hold of the whole world since then (World Health Organization, 2020). According to UNESCO (2021), 156.692.641 students have been affected by the pandemic. Schools all over the world have turned to distance learning to provide students with their learning needs.

Distance learning is defined in different ways. However, in the broadest sense, it is a planned, systematic, and institutional education model in which a source (teacher) and a recipient (student), who are physically separated 
from each other, carry out educational activities and interaction through various technological tools (computer, television, video, etc.) and systems (Internet) (Moore \& Diehl, 2003; Moore \& Kearsley, 2005; Uşun, 2006; İşman, 2011; Simonson, Smaldino, Albright, \& Zvacek, 2012).

Distance learning used to be done through mail, radio, and TV in the past when technology was not as prevalent as it is now. However, today, it is an online learning environment. Web-based distance learning is conducted either synchronously or asynchronously (Karatepe, Küçükgençay, \& Peker, 2020). There are some differences between synchronous and asynchronous types of distance learning. Synchronous distance learning involves student-teacher interaction and allows students to ask questions, discuss subject matters, and do tests. In asynchronous distance learning, students can access course materials and complete assignments whenever and wherever they want (Toker-Gökçe, 2008). As with any kind of face-to-face education, distance learning has its pros and cons.

The advantages of distance learning are that it is a cost- and time-effective method that promotes life-long learning and provides equal opportunities to a wide range of learners, and allows them to access courses whenever and wherever they want (Odabaş, 2003; Arat \& Bakan, 2014; Traxler, 2018). On the other hand, the disadvantages of distance learning are limited interaction, technical issues, low readiness on the part of learners, and economic constraints (Karakuş, Ucuzsatar, Karacaoğlu, Esendemir, \& Bayraktar, 2020). Therefore, we can argue that distance learning is superior to traditional classroom learning in some respects but inferior in others. We should set all components of distance learning to work to overcome those disadvantages.

Communication technologies play a crucial role in distance learning. The other main components of distance learning are (1) individuals responsible for content development, (2) individuals developing course materials suitable for the content, (3) teachers, (4) support staff, (5) students, and (6) a management unit that sets all educational policies and coordinates all components (Moore \& Diehl, 2003). The quality of distance learning depends very much on teachers' satisfaction, opinions, or perspectives (Dooley \& Murphrey, 2000; Harris \& Krousgrill, 2008). In other words, teachers' judgments or attitudes towards distance learning are critical factors that determine its quality. Therefore, we think that teachers' attitudes and views can provide us with valuable information regarding what should be done to improve distance learning. In this context, this paper investigated Turkish teachers' attitudes towards distance learning, which has been implemented since the onset of the COVID-19 pandemic to ensure continuity in education. The main research questions are as follows:

1) What kind of attitudes do Turkish teachers have towards distance learning?

2) Is there a difference between male and female Turkish teachers' attitudes towards distance learning?

3) Is there a difference between public and private school teachers' attitudes towards distance learning?

4) Do Turkish teachers' attitudes towards distance learning differ by degree?

5) Do Turkish teachers' attitudes towards distance learning differ by work experience?

6) Do Turkish teachers' attitudes towards distance learning differ by their knowledge and experience in distance learning?

\section{Method}

\subsection{Research Model}

This study adopted a mixed-method research design involving quantitative and qualitative stages. A mixed-method research design is based on multiple data collection through different strategies and approaches (Johnson \& Turner, 2003). According to Creswell and Plano Clark (2017), using quantitative and qualitative approaches together allows us to better understand research problems than using each alone. Baki and Gökçek (2012) also argue that a mixed-method design helps researchers answer research questions more broadly and completely. We supported quantitative data with qualitative data to better understand the phenomenon in question.

\subsection{Study Group}

The quantitative data were collected from 292 voluntary Turkish teachers. Table 1 shows their demographic characteristics (gender, work experience, major, degree, and school type). 
Table 1. Demographic characteristics $(n=292)$

\begin{tabular}{llcc}
\hline \multirow{2}{*}{ Gender } & & $\mathrm{f}$ & $\%$ \\
\hline \multirow{4}{*}{ Work experience (year) } & Woman & 140 & 47.9 \\
& Man & 152 & 52.1 \\
\cline { 2 - 4 } & $1-5$ & 132 & 45.2 \\
& $11-15$ & 18 & 26.7 \\
& $\geq 16$ & 48 & 16.4 \\
\multirow{3}{*}{ Major } & Turkish teaching & 34 & 11.6 \\
& Turkish language and literature & 254 & 87.0 \\
& Turkish language and literature Teaching & 18 & 6.2 \\
\multirow{2}{*}{ Degree } & Others & 10 & 3.4 \\
& Bachelor's & 10 & 3.4 \\
\hline \multirow{2}{*}{ School type } & Master's & 222 & 76.0 \\
& Public & 70 & 24.0 \\
\hline & Private & 284 & 97.3 \\
& & 8 & 2.7 \\
\hline
\end{tabular}

The sample of the quantitative stage consisted of 292 voluntary Turkish teachers. More than half the participants were women $(\mathrm{n}=140 ; 47.9 \%)$. Less than half the participants $(\mathrm{n}=132 ; 45.2 \%)$ had 1 to 5 years of work experience. A quarter of the participants $(\mathrm{n}=18 ; 26.7 \%)$ had 6 to 10 years of work experience. Forty-eight participants $(16.4 \%)$ had 11 to 15 years of work experience. Thirty-four $(11.6 \%)$ had more than 15 years of work experience. Most participants $(\mathrm{n}=254 ; 87 \%)$ majored in Turkish Teaching. Eighteen participants $(6.2 \%)$ majored in Turkish Language and Literature. Ten participants (3.4\%) majored in Turkish Language and Literature Teaching. Ten participants (3.4\%) majored in other fields. The majority of the participants $(\mathrm{n}=222 ; 76 \%)$ had a bachelor's degree, while the remaining $(n=70 ; 24 \%)$ had a master's degree. Most participants were public school teachers $(n=284$; 97.3\%), while the remaining eight were private school teachers (2.7\%) (Table 1).

The qualitative data were collected from ten voluntary Turkish teachers recruited using purposive convenience sampling. Participants were assigned codes (P1, P2, etc.) to ensure confidentiality and anonymity. Table 1 shows their demographic characteristics.

Table 2. Demographic Characteristics $(\mathrm{n}=10)$

\begin{tabular}{|c|c|c|c|c|c|c|c|c|c|}
\hline \multirow{2}{*}{ Participant } & \multicolumn{3}{|c|}{ Work experience (year) } & \multicolumn{2}{|c|}{ Degree } & \multicolumn{2}{|c|}{ School type } & \multicolumn{2}{|c|}{ Gender } \\
\hline & $1-5$ & $6-9$ & $\geq 10$ & Bachelor's & Master's & Public & Private & Woman & Man \\
\hline $\mathrm{P} 1$ & & $\mathrm{x}$ & & $\mathrm{x}$ & & $\mathrm{x}$ & & $\mathrm{x}$ & \\
\hline $\mathrm{P} 2$ & & $\mathrm{x}$ & & $\mathrm{x}$ & & $\mathrm{x}$ & & $\mathrm{x}$ & \\
\hline P3 & & $\mathrm{x}$ & & $\mathrm{x}$ & & $\mathrm{x}$ & & & $\mathrm{x}$ \\
\hline P4 & $\mathrm{x}$ & & & & $\mathrm{x}$ & $\mathrm{x}$ & & & $\mathrm{x}$ \\
\hline P5 & $\mathrm{x}$ & & & & $\mathrm{x}$ & $\mathrm{x}$ & & & $\mathrm{x}$ \\
\hline P6 & $\mathrm{x}$ & & & & $\mathrm{x}$ & $\mathrm{x}$ & & $\mathrm{x}$ & \\
\hline P7 & $\mathrm{x}$ & & & & $\mathrm{x}$ & $\mathrm{x}$ & & $\mathrm{x}$ & \\
\hline P8 & & $\mathrm{x}$ & & & $\mathrm{x}$ & $\mathrm{x}$ & & $\mathrm{x}$ & \\
\hline P9 & & $\mathrm{x}$ & & & $\mathrm{x}$ & $\mathrm{x}$ & & $\mathrm{x}$ & \\
\hline $\mathrm{P} 10$ & & & $\mathrm{x}$ & $\mathrm{x}$ & & $\mathrm{x}$ & & & $\mathrm{x}$ \\
\hline
\end{tabular}

The sample of the qualitative stage consisted of ten voluntary Turkish teachers (six women and four men). All participants were public school teachers. Six participants had a master's degree, while the remaining had a bachelor's degree. Five participants had 6 to 9 years of work experience. Four participants had 1 to 5 years of work experience. One participant had ten years of work experience (Table 2).

\subsection{Data Collection}

The quantitative data were collected using a demographic characteristics questionnaire and the Distance Learning Attitude Scale (DLAS) (Note 1) developed by Ağır (2007).

The Distance Learning Attitude Scale (DLAS) is a five-point Likert-type instrument consisting of 21 items. 
Fourteen items are positive statements, while the remaining seven $(11,12,13,14,15,17$, and 19) are negative statements that are reverse scored. The total score ranges from 21 to 105 . Higher scores indicate more positive attitudes towards distance learning. The scale consists of two subscales: "advantages of distance learning (ADL)" and "limitations of distance learning (LDL)." Ağır (2017) conducted exploratory and confirmatory factor analyses and reported that the scale had both high reliability and validity as a measure of attitudes towards distance learning. The total scale has a Cronbach's alpha (internal consistency) of 0.881. The subscales ADL and LDL have a Cronbach's alpha of 0.887 and 0.797, respectively (Ağır, 2007). In this study, the DLAS, ADL, and LDL had a Cronbach's alpha of $0.872,0.895$, and 0.786 , respectively. A Cronbach's alpha of greater than 0.7 is considered sufficient for reliability (Büyüköztürk, 2011). Therefore, the results showed that the DLAS was a reliable measure of attitudes towards distance learning.

The qualitative data were collected through focus group interviews using a semi-structured interview form.

\subsection{Data Analysis}

The quantitative data were analyzed using the Statistical Package for Social Sciences (SPSS, v. 21) at a significance level of 0.05 . Descriptive statistics (frequency, percentage, arithmetic mean, and standard deviation) were used for analysis. The Kolmogorov-Smirnov test was used for normality testing. The results showed that most data were normally distributed ( $p>0.05$ ). Therefore, the data were analyzed using parametric tests, except for the variable "school type" because one of the groups consisted of less than 30 participants. A t-test was used to determine whether participants' attitudes towards distance learning differed by "gender" and "degree." An ANOVA was used to determine whether participants' attitudes towards distance learning differed by "work experience" and "knowledge and experience in distance learning." A Scheffe's Test was used to make posthoc comparisons to determine the source of significant differences. The Mann-Whitney $U$ test was used to determine whether participants' attitudes towards distance learning differed by "school type."

The qualitative data were analyzed using content analysis. The two researchers analyzed the interviews together. They transcribed and conceptualized all participants' responses. They organized the responses in accordance with the emerging concepts and classified them into themes. They also used direct quotations to provide an accurate and coherent picture of participants' views of distance learning.

\section{Results}

Table 3 shows the numerical distribution of participants' responses to the DSAL items.

Table 3. Numerical distribution of participants' responses to DSAL items

\begin{tabular}{|c|c|c|c|c|c|c|c|c|c|c|c|}
\hline \multirow{2}{*}{ Items } & \multicolumn{2}{|c|}{ Strongly Disagree } & \multicolumn{2}{|c|}{ Disagree } & \multicolumn{2}{|c|}{ Undecided } & \multicolumn{2}{|c|}{ Agree } & \multicolumn{2}{|c|}{ Strongly Agree } & \multirow{2}{*}{$\mathrm{X}$} \\
\hline & $\mathrm{f}$ & $\%$ & $\mathrm{f}$ & $\%$ & $\mathrm{f}$ & $\%$ & $\mathrm{f}$ & $\%$ & $\mathrm{f}$ & $\%$ & \\
\hline 1 & 64 & 21.9 & 80 & 27.4 & 66 & 22.6 & 74 & 25.3 & 8 & 2.7 & 2.59 \\
\hline 2 & 42 & 14.4 & 40 & 13.7 & 44 & 15.1 & 114 & 39.0 & 52 & 17.8 & 3.32 \\
\hline 3 & 24 & 8.2 & 14 & 4.8 & 22 & 7.5 & 124 & 42.5 & 108 & 37.0 & 3.95 \\
\hline 4 & 34 & 11.6 & 18 & 6.2 & 0 & 0 & 40 & 13.7 & 200 & 68.5 & 4.21 \\
\hline 5 & 26 & 8.9 & 28 & 9.6 & 64 & 21.9 & 134 & 45.9 & 40 & 13.7 & 3.45 \\
\hline 6 & 20 & 6.8 & 26 & 8.9 & 42 & 14.4 & 94 & 32.2 & 110 & 37.7 & 3.84 \\
\hline 7 & 74 & 25.3 & 46 & 15.8 & 72 & 24.7 & 68 & 23.3 & 32 & 11.0 & 2.78 \\
\hline 8 & 46 & 15.8 & 44 & 15.1 & 84 & 28.8 & 80 & 27.4 & 38 & 13.0 & 3.06 \\
\hline 9 & 14 & 4.8 & 20 & 6.8 & 38 & 13.0 & 98 & 33.6 & 122 & 41.8 & 4.00 \\
\hline 10 & 16 & 5.5 & 24 & 8.2 & 32 & 11.0 & 126 & 43.2 & 94 & 32.2 & 3.88 \\
\hline 11 & 12 & 4.1 & 18 & 6.2 & 56 & 19.2 & 84 & 28.8 & 122 & 41.8 & 3.97 \\
\hline 12 & 32 & 11.0 & 56 & 19.2 & 94 & 32.2 & 90 & 30.8 & 20 & 6.8 & 3.03 \\
\hline 13 & 6 & 2.1 & 18 & 6.2 & 24 & 8.2 & 76 & 26.0 & 168 & 57.5 & 4.30 \\
\hline 14 & 12 & 4.1 & 62 & 21.2 & 98 & 33.6 & 68 & 23.3 & 52 & 17.8 & 3.29 \\
\hline 15 & 178 & 61.0 & 66 & 22.6 & 20 & 6.8 & 16 & 5.5 & 12 & 4.1 & 1.69 \\
\hline 16 & 48 & 16.4 & 46 & 15.8 & 98 & 33.6 & 76 & 26.0 & 24 & 8.2 & 2.93 \\
\hline 17 & 24 & 8.2 & 66 & 22.6 & 110 & 37.7 & 56 & 19.2 & 36 & 12.3 & 3.04 \\
\hline 18 & 32 & 11.0 & 64 & 21.9 & 100 & 34.2 & 64 & 21.9 & 32 & 11.0 & 3.00 \\
\hline 19 & 14 & 4.8 & 54 & 18.5 & 78 & 26.7 & 84 & 28.8 & 62 & 21.2 & 3.43 \\
\hline 20 & 40 & 13.7 & 64 & 21.9 & 76 & 26.0 & 60 & 20.5 & 52 & 17.8 & 3.06 \\
\hline 21 & 44 & 15.1 & 62 & 21.2 & 54 & 18.5 & 94 & 32.2 & 38 & 13.0 & 3.06 \\
\hline
\end{tabular}


The mean scores ranged from 1.69 to 4.30 . Attitude ranges were determined using the equation $5-1 / 5=0.8$. Based on this value, the attitude ranges were as follows: " $0.8+1=1.8$ very negative attitudes," " $1.8+0.8=2.6$ negative attitudes," "2. $6+0.8=3.4$ moderate attitudes," " $3.4+0.8=4.2$ positive attitudes," and " $4.2+0.8=5.0$ very positive attitudes." The results showed that participants had very positive attitudes towards some aspects of distance learning, whereas they had very negative attitudes towards some other aspects of distance learning.

A t-test was conducted to determine the effect of gender on DSAL scores (Table 4).

Table 4. T-test results regarding the effect of gender on DSAL scores

\begin{tabular}{cccccccc}
\hline Scale & Gender & $\mathrm{n}$ & $\mathrm{X}$ & $\mathrm{SS}$ & $\mathrm{t}$ & $\mathrm{sd}$ & $\mathrm{p}$ \\
\hline \multirow{2}{*}{ ADL } & Woman & 140 & 47.42 & 6.40 & \multirow{2}{*}{0.771} & \multirow{2}{*}{290} & \multirow{2}{*}{0.441} \\
& Man & 152 & 46.86 & 6.00 & & & \\
\hline \multirow{2}{*}{ LDL } & Woman & 140 & 22.87 & 3.44 & \multirow{2}{*}{0.042} & \multirow{2}{*}{290} & 0.967 \\
& Man & 152 & 22.85 & 3.17 & & & \\
\hline \multirow{2}{*}{ DSAL Total } & Woman & 140 & 70.30 & 7.70 & \multirow{2}{*}{0.661} & \multirow{2}{*}{290} & 0.509 \\
& Man & 152 & 69.72 & 7.20 & & & \\
\hline
\end{tabular}

There was no statistically significant difference in DSAL $\left[\mathrm{t}_{(290)}=0.661 ; \mathrm{p}>0.05\right]$, ADL $\left[\mathrm{t}_{(290)}=0.771 ; \mathrm{p}>0.05\right]$, and LDL $\left[\mathrm{t}_{(290)}=0.42 ; \mathrm{p}>0.05\right]$ scores between male and female participants. This result indicated that gender had no effect on participants' attitudes towards distance learning (Table 4).

The interviews also did not reveal a connection between gender and attitudes towards distance learning. Both female (P1, P2, P6, P7, P8, and P9) and male (P5 and P10) participants stated that they believed that face-to-face learning was better than distance learning. Only two male participants (P3 and P4) noted that distance and face-to-face learning had their own advantages. Therefore, we can state that the qualitative data corroborated the quantitative findings:

P3: Distance learning can be as effective [as face-to-face learning] as long as there is participation. However, its effectiveness depends on the topic, the learning outcome, the course, and the skills.

P7: I think that face-to-face learning is more effective [than distance learning] because it's easier to keep students under control during face-to-face learning, but I also think that distance learning is better in the sense that it helps us contain the virus and decrease the spread of illness.

The Mann-Whitney U test was used to determine whether the school type affected participants' attitudes towards distance learning (Table 5).

Table 5. Mann-Whitney U test results regarding the effect of school type on DSAL scores

\begin{tabular}{cccccccc}
\hline Scale & School Type & N & Mean Rank & Rank Sum & U & p \\
\hline \multirow{2}{*}{ ADL } & Public & 284 & 148.46 & 42162.00 & \multirow{2}{*}{580.00} & \multirow{2}{*}{$0.018^{*}$} \\
& Private & 8 & 77.00 & 616.00 & \\
\hline \multirow{2}{*}{ LDL } & Public & 284 & 144.68 & 41088.00 & \multirow{2}{*}{618.00} & \multirow{2}{*}{$0.027^{*}$} \\
& Private & 8 & 211.25 & 1690.00 & & \multirow{2}{*}{0.211} \\
\hline \multirow{2}{*}{ DSAL Total } & Public & 284 & 147.54 & 41900.00 & \multirow{2}{*}{842.00} & \multirow{2}{*}{0.211} \\
& Private & 8 & 109.75 & 878.00 & & & \\
\hline
\end{tabular}

$* \mathrm{p}<0.05$.

There was no statistically significant difference in DSAL scores between public and private school teachers $(p>0.05)$. However, there were significant differences in ADL $(U=580.00)$ and $L D L(U=618.00)$ scores between public and private school teachers $(\mathrm{p}<0.05)$. This result showed that participants' attitudes towards the advantages and limitations of distance learning differed by what type of school they worked for. Public school teachers had a higher mean ADL subscale score (148.46) than private school teachers (77.00). This result suggested that public school teachers believed that distance learning had more advantages than private school teachers. On the other hand, private school teachers had a higher mean LDL subscale score (211.25) than public school teachers (144.68). This result showed that private school teachers believed that distance learning had more limitations than public school teachers. 
The effect of degree on DSAL scores was determined using a t-test (Table 6).

Table 6. T-test results regarding the effect of degree on DSAL scores

\begin{tabular}{|c|c|c|c|c|c|c|c|}
\hline Scale & Degree & $\mathrm{n}$ & $\mathrm{X}$ & SS & $\mathrm{t}$ & $\mathrm{sd}$ & $\mathrm{p}$ \\
\hline \multirow{2}{*}{$\mathrm{ADL}$} & Bachelor's & 222 & 46.79 & 6.23 & \multirow{2}{*}{-1.69} & \multirow{2}{*}{290} & \multirow{2}{*}{0.091} \\
\hline & Master's & 70 & 48.22 & 5.96 & & & \\
\hline \multirow{2}{*}{ LDL } & Bachelor's & 222 & 22.76 & 3.39 & \multirow{2}{*}{-0.89} & \multirow{2}{*}{290} & \multirow{2}{*}{0.371} \\
\hline & Master's & 70 & 23.17 & 3.01 & & & \\
\hline \multirow{2}{*}{ DSAL Total } & Bachelor's & 222 & 69.55 & 7.79 & \multirow{2}{*}{-1.81} & \multirow{2}{*}{290} & \multirow{2}{*}{0.071} \\
\hline & Master's & 70 & 71.40 & 5.99 & & & \\
\hline
\end{tabular}

There was no statistically significant difference in DSAL [ $\left.\mathrm{t}_{(290)}=0.071 ; \mathrm{p}>0.05\right]$, ADL [ $\left.\mathrm{t}_{(290)}=0.991 ; \mathrm{p}>0.05\right]$, and LDL $\left[\mathrm{t}_{(290)}=0.371 ; \mathrm{p}>0.05\right]$ scores between participants with a bachelor's and master's degree. This result showed that participants' attitudes did not differ by degree (Table 6).

The qualitative data were consistent with the quantitative findings. Participants with a bachelor's degree (P1, P2, and P10) and master's degree (P5, P6, P7, P8, and P9) had similar attitudes towards distance and face-to-face learning.

P8: Face-to-face learning is more effective and useful [than distance learning]. Face-to-face learning allows us to reach as many students as possible. It's pretty effective because it lets teachers deliver lectures face-to-face and make eye contact with students.

P10: I think that face-to-face learning is more effective [than distance learning]. I couldn't be of much help to my students during distance learning. Some of my students, actually, most of them, do not have the socioeconomic means to attend distance learning, which has drastic consequences.

An ANOVA test was used to identify whether work experience affected participants' attitudes towards distance learning (Table 7).

Table 7. ANOVA test results regarding the effect of work experience on DSAL scores

\begin{tabular}{|c|c|c|c|c|c|c|c|c|c|c|}
\hline Scale & $\begin{array}{c}\text { Work } \\
\text { experience } \\
\text { (year) }\end{array}$ & $\mathrm{N}$ & $X$ & SS & $\begin{array}{l}\text { Source of } \\
\text { Variance }\end{array}$ & Sum of Squares & $\mathrm{sd}$ & $\begin{array}{c}\text { Mean } \\
\text { Square }\end{array}$ & $\mathrm{F}$ & $\mathrm{p}$ \\
\hline $\mathrm{ADL}$ & $\begin{array}{c}1-5 \\
6-10 \\
11-15 \\
\geq 16 \\
\end{array}$ & $\begin{array}{c}132 \\
78 \\
48 \\
34\end{array}$ & $\begin{array}{l}48.50 \\
46.92 \\
46.62 \\
43.05\end{array}$ & $\begin{array}{l}5.39 \\
6.48 \\
6.10 \\
6.85\end{array}$ & $\begin{array}{c}\text { Between } \\
\text { groups } \\
\text { Within } \\
\text { groups } \\
\text { Total }\end{array}$ & $\begin{array}{c}826.850 \\
10339.671 \\
111666.521\end{array}$ & $\begin{array}{c}3 \\
288 \\
291\end{array}$ & $\begin{array}{c}275.617 \\
35.902\end{array}$ & 7.677 & $0.000 *$ \\
\hline LDL & $\begin{array}{c}1-5 \\
6-10 \\
11-15 \\
\geq 16\end{array}$ & $\begin{array}{c}132 \\
78 \\
48 \\
34\end{array}$ & $\begin{array}{l}22.65 \\
22.69 \\
24.25 \\
22.11\end{array}$ & $\begin{array}{l}3.24 \\
3.56 \\
2.75 \\
3.20\end{array}$ & $\begin{array}{c}\text { Between } \\
\text { groups } \\
\text { Within } \\
\text { groups } \\
\text { Total } \\
\end{array}$ & $\begin{array}{c}119.406 \\
3055.114 \\
3174.521\end{array}$ & $\begin{array}{c}3 \\
288 \\
291\end{array}$ & $\begin{array}{l}39.802 \\
10.608\end{array}$ & 3.752 & $0.011 *$ \\
\hline $\begin{array}{c}\text { DSAL } \\
\text { Total }\end{array}$ & $\begin{array}{c}1-5 \\
6-10 \\
11-15 \\
\geq 16\end{array}$ & $\begin{array}{c}132 \\
78 \\
48 \\
34\end{array}$ & $\begin{array}{l}71.15 \\
69.61 \\
70.87 \\
65.17\end{array}$ & $\begin{array}{l}7.00 \\
7.93 \\
6.81 \\
7.02\end{array}$ & $\begin{array}{c}\text { Between } \\
\text { groups } \\
\text { Within } \\
\text { groups } \\
\text { Total }\end{array}$ & $\begin{array}{c}1014.378 \\
15085.622 \\
16100.000\end{array}$ & $\begin{array}{c}3 \\
288 \\
291\end{array}$ & $\begin{array}{c}388.126 \\
52.381\end{array}$ & 6.455 & $0.000 *$ \\
\hline
\end{tabular}

$* \mathrm{p}<0.05$.

Participants' DSAL $\left[\mathrm{F}_{(3-291)}=6.455 ; \mathrm{p}<0.05\right]$, ADL $\left[\mathrm{F}_{(3-291)}=7.677 ; \mathrm{p}<0.05\right]$, and $\operatorname{LDL}\left[\mathrm{F}_{(3-291)}=3.752 ; \mathrm{p}<0.05\right]$ scores significantly differed by work experience (Table 7). This result suggested that work experience affected participants' attitudes towards distance learning.

A Scheffe's test was used to make posthoc comparisons between the groups to determine the source of the 
significant differences. Table 8 shows the results.

Table 8. Scheffe's test results

\begin{tabular}{|c|c|c|c|c|c|}
\hline Scale & $\begin{array}{c}\text { Groups (I) } \\
\text { (year) }\end{array}$ & $\begin{array}{c}\text { Groups }(\mathrm{J}) \\
\text { (year) }\end{array}$ & Mean Difference (I-J) & Standard Error & $\mathrm{p}$ \\
\hline \multirow{12}{*}{$\begin{array}{l}\text { ADL } \\
\text { LDL } \\
\text { ADL }\end{array}$} & \multirow{3}{*}{$1-5$} & $6-10$ & 1.57692 & 0.855 & 0.336 \\
\hline & & $11-15$ & 1.87500 & 1.009 & 0.330 \\
\hline & & $\geq 16$ & 5.44118 & 1.152 & $0.000^{*}$ \\
\hline & \multirow{3}{*}{$6-10$} & $1-5$ & -1.57692 & 0.855 & 0.336 \\
\hline & & $11-15$ & 0.29808 & 1.009 & 0.995 \\
\hline & & $\geq 16$ & 3.86425 & 1.231 & $0.021 *$ \\
\hline & \multirow{3}{*}{$11-15$} & $1-5$ & -1.87500 & 1.009 & 0.330 \\
\hline & & $6-10$ & -0.29808 & 1.099 & 0.995 \\
\hline & & $\geq 16$ & 3.56618 & 1.343 & 0.073 \\
\hline & \multirow{3}{*}{$\geq 16$} & $1-5$ & -5.44118 & 1.152 & $0.000^{*}$ \\
\hline & & $6-10$ & -3.86425 & 1.231 & $0.021^{*}$ \\
\hline & & $11-15$ & -3.56618 & 1.343 & 0.073 \\
\hline \multirow{12}{*}{$\begin{array}{l}\text { LDL } \\
\text { ADL } \\
\text { LDL }\end{array}$} & \multirow{3}{*}{$1-5$} & $6-10$ & -0.4079 & 0.465 & 1.000 \\
\hline & & $11-15$ & -1.59848 & 0.548 & $0.039^{*}$ \\
\hline & & $\geq 16$ & 0.53387 & 0.626 & 0.867 \\
\hline & \multirow{3}{*}{$6-10$} & $1-5$ & 0.4079 & 0.465 & 1.000 \\
\hline & & $11-15$ & -1.55769 & 0.597 & 0.081 \\
\hline & & $\geq 16$ & 0.57466 & 0.669 & 0.864 \\
\hline & \multirow{3}{*}{$11-15$} & $1-5$ & 1.59848 & 0.548 & $0.039 *$ \\
\hline & & $6-10$ & 1.55769 & 0.597 & 0.081 \\
\hline & & $\geq 16$ & 2.13235 & 0.730 & $0.038^{*}$ \\
\hline & \multirow{3}{*}{$\geq 16$} & $1-5$ & -0.53387 & 0.626 & 0.867 \\
\hline & & $6-10$ & -0.57466 & 0.669 & 0.864 \\
\hline & & $11-15$ & -2.13235 & 0.730 & $0.038^{*}$ \\
\hline \multirow{12}{*}{ DSAL Total } & \multirow{3}{*}{$1-5$} & $6-10$ & 1.53613 & 1.033 & 0.531 \\
\hline & & $11-15$ & 0.27652 & 1.219 & 0.997 \\
\hline & & $\geq 16$ & 5.97504 & 1.391 & $0.000 *$ \\
\hline & \multirow{3}{*}{$6-10$} & $1-5$ & -1.53613 & 1.033 & 0.531 \\
\hline & & $11-15$ & -1.25962 & 1.327 & 0.825 \\
\hline & & $\geq 16$ & 4.43891 & 1.487 & $0.032 *$ \\
\hline & \multirow{4}{*}{$11-15$} & $1-5$ & -0.27652 & 1.219 & 0.997 \\
\hline & & $6-10$ & 1.25962 & 1.327 & 0.825 \\
\hline & & $\geq 16$ & 5.69853 & 1.622 & $0.007^{*}$ \\
\hline & & $1-5$ & -5.97504 & 1.391 & $0.000^{*}$ \\
\hline & \multirow[t]{2}{*}{$\geq 16$} & $6-10$ & -4.43891 & 1.487 & $0.032 *$ \\
\hline & & $11-15$ & -5.69853 & 1.622 & $0.007 *$ \\
\hline
\end{tabular}

$* \mathrm{p}<0.05$.

There was a statistically significant difference in ADL subscale scores between participants with 1 to 5 years of work experience $(X=48.50)$ and those with more than 15 years of work experience $(X=43.05)$. Participants with 1 to 5 years of work experience had a significantly higher mean ADL subscale score $(X=48.50)$ than those with more than 15 years of work experience $(X=43.05)$. There was also a statistically significant difference in ADL subscale scores between participants with 6 to 10 years of work experience $(X=46.92)$ and those with more than 15 years of work experience $(X=43.05)$ (Table 8). Participants with 6 to 10 years of work experience had a significantly higher mean ADL subscale score $(X=46.92)$ than those with more than 15 years of work experience $(X=43.05)$. These results indicated that participants with less work experience believed that distance learning had more advantages.

There was a statistically significant difference in LDL subscale scores between participants with 11 to 15 years of work experience $(X=24.25)$ and those with 1 to 5 years of work experience $(X=22.65)$. There was also a statistically significant difference in LDL subscale scores between participants with 11 to 15 years of work 
experience $(X=24.25)$ and those with more than 15 years of work experience $(X=22.11)$. Participants with more than 15 years of work experience had the lowest mean LDL subscale score ( $X=22.11)$ (Table 8). These results suggested that participants with more work experience believed that distance learning had fewer limitations.

There was a statistically significant difference in DLAS scores between participants based on work experience. Participants with more than 15 years of work experience $(X=65.17)$ had significantly lower DLAS total scores than those with 1 to $5(X=71.15), 6$ to $10(X=69.61)$, and 11 to $15(X=70.87)$ years of work experience. Participants with 1 to 5 years of work experience had the highest DLAS total score $(X=71.15)$. These results showed that participants in their early years of employment had more positive attitudes towards distance learning than others.

The interviews also revealed that participants' attitudes towards distance learning were impacted by how much work experience they had. Two participants with 8 to 9 years of work experience (P1 and P2) clearly stated that they believed that face-to-face learning was much better than distance learning. On the other hand, a participant with three years of work experience (P4) noted that distance learning could be better than face-to-face learning if infrastructure problems were solved. The quantitative findings corroborated the qualitative data:

P1: Face-to-face learning is definitely better [than distance learning]. It allows us to recognize students' individual differences and respond to them.

P2: I can say that face-to-face learning is indispensable because it helps us see students in person, understand how they feel, communicate with them, and understand each other.

P4: Distance learning can even be better [than face-to-face learning] if given the opportunity. But students should have a sense of responsibility, and teachers should keep up with advances in technology. In distance learning, it's easier to keep students under control through computer commands.

An ANOVA test was performed to determine whether knowledge and experience in distance learning affected participants' attitudes towards it. Table 9 shows the results.

Table 9. ANOVA test results regarding the effect of knowledge and experience in distance learning on DSAL scores

\begin{tabular}{|c|c|c|c|c|c|c|c|c|c|c|}
\hline Scale & $\begin{array}{c}\text { Knowledge and } \\
\text { Experience }\end{array}$ & $\mathrm{N}$ & $\mathrm{X}$ & SS & $\begin{array}{l}\text { Source of } \\
\text { Variance }\end{array}$ & $\begin{array}{l}\text { Sum of } \\
\text { Squares }\end{array}$ & sd & $\begin{array}{c}\text { Mean } \\
\text { Square }\end{array}$ & $\mathrm{F}$ & $\mathrm{p}$ \\
\hline \multirow{3}{*}{$\mathrm{ADL}$} & Very little & 106 & 44.67 & 5.66 & Between groups & 1240.216 & 2 & \multirow{3}{*}{$\begin{array}{c}620.108 \\
34.347\end{array}$} & \multirow{3}{*}{18.054} & \multirow{3}{*}{$0.000^{*}$} \\
\hline & Enough & 144 & 47.93 & 6.22 & Within groups & 9926.305 & 289 & & & \\
\hline & Much & 42 & 50.61 & 4.95 & Total & 11166.521 & 291 & & & \\
\hline \multirow{3}{*}{ LDL } & Very little & 106 & 22.71 & 3.19 & Between groups & 85.884 & 2 & \multirow{3}{*}{$\begin{array}{l}42.942 \\
10.687\end{array}$} & \multirow{3}{*}{4.018} & \multirow{3}{*}{$0.019^{*}$} \\
\hline & Enough & 144 & 23.30 & 3.52 & Within groups & 3088.636 & 289 & & & \\
\hline & Much & 42 & 21.71 & 2.42 & Total & 3174.521 & 291 & & & \\
\hline \multirow{3}{*}{$\begin{array}{l}\text { DSAL } \\
\text { Total }\end{array}$} & Very little & 106 & 67.39 & 7.61 & Between groups & 1167.336 & 2 & \multirow{3}{*}{$\begin{array}{c}583.668 \\
51.670\end{array}$} & \multirow{3}{*}{11.296} & \multirow{3}{*}{$0.000^{*}$} \\
\hline & Enough & 144 & 71.23 & 7.44 & Within groups & 14932.664 & 289 & & & \\
\hline & Much & 42 & 72.33 & 4.75 & Total & 16100.000 & 291 & & & \\
\hline
\end{tabular}

${ }^{*} \mathrm{p}<0.05$.

Participants' DSAL total $\left[\mathrm{F}_{(2-291)}=11.296 ; \mathrm{p}<0.05\right]$ and ADL $\left[\mathrm{F}_{(2-291)}=18.054 ; \mathrm{p}<0.05\right]$ and $\operatorname{LDL}\left[\mathrm{F}_{(2-291)}=4.018\right.$; $\mathrm{p}<0.05]$ subscale scores significantly differed by their knowledge and experience in distance learning. This result showed that knowledge and experience in distance learning was a significant factor affecting participants' attitudes towards it (Table 9).

A Scheffe's test was performed to make posthoc comparisons to determine the source of the significant differences between the groups. Table 10 shows the results. 
Table 10. Scheffe's test results regarding the effect of knowledge and experience in distance learning on scale scores

\begin{tabular}{|c|c|c|c|c|c|}
\hline Scale & $\begin{array}{c}\text { Groups (I) } \\
\text { (experience) }\end{array}$ & $\begin{array}{c}\text { Groups (J) } \\
\text { (experience) }\end{array}$ & Mean Difference (I-J) & Standard Error & $\mathrm{p}$ \\
\hline \multirow{6}{*}{$\mathrm{ADL}$} & \multirow{2}{*}{ Very little } & \multirow{2}{*}{ Enough Much } & -3.25131 & 0.75 & $0.000^{*}$ \\
\hline & & & -5.93980 & 1.06 & $0.000 *$ \\
\hline & \multirow{2}{*}{ Enough } & Very little & 3.25131 & 0.75 & $0.000^{*}$ \\
\hline & & Much & -2.68849 & 1.02 & $0.034 *$ \\
\hline & \multirow{2}{*}{ Much } & Very little & 5.93980 & 1.06 & $0.000 *$ \\
\hline & & Enough & 2.68849 & 1.02 & $0.034 *$ \\
\hline \multirow{6}{*}{ LDL } & \multirow{2}{*}{ Very little } & \multirow{2}{*}{ Enough Much } & -0.58857 & 0.41 & 0.373 \\
\hline & & & 1.00270 & 0.59 & 0.245 \\
\hline & \multirow{2}{*}{ Enough } & Very little & 0.58857 & 0.41 & 0.373 \\
\hline & & Much & 1.59127 & 0.57 & $0.022 *$ \\
\hline & \multirow{2}{*}{ Much } & Very little & -1.00270 & 0.59 & 0.245 \\
\hline & & Enough & -1.59127 & 0.57 & $0.022 *$ \\
\hline \multirow{6}{*}{$\begin{array}{c}\text { DSAL } \\
\text { Total }\end{array}$} & \multirow{2}{*}{ Very little } & \multirow{2}{*}{ Enough Much } & -3.83988 & 0.91 & $0.000 *$ \\
\hline & & & -4.93711 & 1.31 & $0.001 *$ \\
\hline & \multirow{2}{*}{ Enough } & Very little & 3.83988 & 0.91 & $0.000 *$ \\
\hline & & Much & -1.09722 & 1.26 & 0.685 \\
\hline & \multirow{2}{*}{ Much } & Very little & 4.93711 & 1.31 & $0.001 *$ \\
\hline & & Enough & 1.09722 & 1.26 & 0.685 \\
\hline
\end{tabular}

$* \mathrm{p}<0.05$.

Participants were divided into three groups based on knowledge and experience in distance learning: "very little," "enough," and "much." There were significant differences in ADL subscale scores between all groups. The more the knowledge and experience in distance learning, the higher the ADL subscale scores, indicating that participants with more knowledge and experience in distance learning believed it had more advantages.

Participants with enough knowledge and experience in distance learning had a higher mean LDL score $(X=23.30)$ than those with much knowledge and experience in distance learning ( $X=21.71)$ (Table 10). This result suggested that participants with enough knowledge and experience in distance learning believed it had more limitations.

Participants with very little knowledge and experience in distance learning had a significantly lower DSAL total score $(X=67.39)$ than those with enough $(X=71.23)$ and much $(X=72.33)$ knowledge and experience in distance learning (Table 10). This result showed that participants with more knowledge and experience in distance learning had more positive attitudes towards it.

The qualitative data also supported this finding. One of the participants (P1) stated that face-to-face learning was better than distance learning. She drew attention to the fact that she faced various problems, especially due to her low level of technological knowledge. Another participant (P6) with a high level of knowledge in technology and computer use focused on the advantages of distance learning:

P1: Dealing with computers and technology was an important step to adapt to the technology of the future. But, at first, we had connection and sound problems because we were trying to learn by trial and error without knowing much about the [distance learning] platform.

P6: I can say that; I mean, I think that it was very helpful for both me and my students to use different distance learning platforms. Before anything else, we live in an age of technology, so I think it helps us use technological tools and devices much better. We used a platform with a solid infrastructure, I mean, ZOOM, which made distance learning more effective.

\section{Conclusion and Discussion}

Participants had positive attitudes towards some aspects of distance learning but negative attitudes towards some others. This result shows that Turkish teachers are capable of recognizing the pros and cons of distance learning. Turkish teachers are eager to implement distance learning, but they sometimes approach it with suspicion due to its disadvantages. Ateş and Altun (2008) reported that preservice computer teachers had precarious attitudes towards distance learning, which is similar to our result. 
Gender did not affect participants' attitudes towards distance learning. The interviews also did not reveal a connection between gender and attitudes towards distance learning. This result is consistent with those reported by earlier studies (Ağır 2007; Ateş \& Altun, 2008; Ülkü, 2018; Moçoşoğlu \& Kaya, 2020). However, our result is different from those of some other studies. For example, Yenilmez, Balbağ, and Turgut (2017) found that male preservice teachers had more positive attitudes towards distance learning than their female counterparts.

There was no significant difference in DLAS scores between public and private school teachers. However, there were significant differences in ADL and LDL subscale scores between public and private school teachers. Public school teachers had a higher mean ADL subscale score than private school teachers, indicating that the former believed that distance learning had more advantages than the latter. On the other hand, private school teachers had a higher mean LDL subscale score than public school teachers, suggesting that the former believed that distance learning had more limitations than did the latter. These results are consistent with those of Ağır (2007). However, unlike our result, Ülkü (2018) and Moçoşoğlu and Kaya (2020) did not find any significant effect of school type on teachers' attitudes towards distance learning.

There was no statistically significant difference in scale scores between participants with a bachelor's and master's degree. The qualitative data also supported this finding. The interviews did not reveal a connection between degree and attitudes towards distance learning. Regardless of degree, participants found face-to-face learning more effective and useful than distance learning. Moçoşoğlu and Kaya (2020) also reported the same result. On the other hand, Ülkü (2018) found that teachers with a master's degree had more positive attitudes towards distance learning than those with an associate's degree.

Participants' DLAS total and ADL and LDL subscale scores significantly differed by work experience. In other words, work experience affected participants' attitudes towards distance learning. Participants with less work experience had more positive attitudes towards distance learning and found it more advantageous. The interviews also corroborated this finding. Two participants with more work experience clearly stated that they believed that face-to-face learning was much better than distance learning, whereas another participant with little work experience remarked that distance learning could be better than face-to-face learning if infrastructure problems were resolved. Ağır (2007), Alea, Fabrea, Roldan, and Farooqi (2020), and Moçoşoğlu and Kaya (2020) also found that teachers with less work experience had more positive attitudes towards distance learning. This is probably because teachers with more work experience are older people who do not know as much about technology as younger teachers, who are more prepared to use technology for education.

Participants with more knowledge and experience in distance learning had more positive attitudes towards it and considered it more advantageous than those with less knowledge and experience in it. The interviews also corroborated this finding. For example, one of the participants with little knowledge and experience in distance learning considered face-to-face learning better than distance learning because she faced various problems during distance learning, primarily due to her low level of technological knowledge. Another participant with a high level of knowledge and experience in technology drew attention to the advantages of distance learning. Therefore, we can state that Turkish teachers who are not tech-savvy tend to avoid using distance learning because they think they may experience some technical problems. This, in turn, causes them to develop negative attitudes towards distance learning. Ateş and Altun (2008) also concluded that computer experience and skills affected users' attitudes towards distance learning. However, Moçoşoğlu and Kaya (2020) did not detect any difference in attitudes towards distance learning between teachers with and without computers at home.

This paper addressed Turkish teachers' attitudes towards distance learning. Future studies should employ different research designs to investigate how teachers from other branches, parents, educational administrators, and students perceive distance learning. Researchers should also focus on the methods and strategies used by stakeholders (teachers, parents, education administrators, students, etc.) to overcome the challenges of distance learning, especially concerning Turkish education.

\section{References}

Ağır, F. (2007). Özel okullarda ve devlet okullarında çalışan ilköğretim öğretmenlerinin uzaktan eğitime karşı tutumlarınin belirlenmesi (Unpublished master's dissertation). Balıkesir University, Balıkesir, Turkey.

Alea, L. A., Fabrea, M. F., Roldan, R. D. A., \& Farooqi, A. Z. (2020). Teachers' Covid-19 awareness, distance learning education experiences and perceptions towards institutional readiness and challenges. International Journal of Learning, Teaching and Educational Research, 19(6), 127-144. https://doi.org/10.26803/ijlter.19.6.8

Arat, T., \& Bakan, Ö. (2014). Uzaktan Eğitim ve Uygulamaları. Selçuk Üniversitesi Sosyal Bilimler Meslek 
Yüksekokulu Dergisi, 14(1-2), 363-374.

Ateş, A., \& Altun, E. (2008). Bilgisayar öğretmeni adaylarının uzaktan eğitime yönelik tutumlarının çeşitli değiş̧kenler açısından incelenmesi. Gazi Eğitim Fakültesi Dergisi, 28(3), 125-145.

Baki, A., \& Gökçek, T. (2012). Karma yöntem araştırmalarına genel bir bakış. Elektronik Sosyal Bilimler Dergisi, $11(42), 1-21$.

Büyüköztürk, Ş. (2011). Sosyal bilimler için veri analizi el kitabı. Ankara: Pegem Academy Publishing.

Cresswell, J. W., \& Plano Clark, V. L. (2017). Designing and conducting mixed methods research. Los Angeles: SAGE Publishing.

Demir, E. (2014). Uzaktan Eğitime Genel Bir Bakış. Dumlupınar Üniversitesi Sosyal Bilimler Dergisi, 39, 203-212.

Dooley, K. E., \& Murphrey, T. P. (2000). How the perspectives of administrators, faculty, and support units impact the rate of distance education adoption. Online Journal of Distance Learning Administration, 3(4), $1-8$.

Harris, D. A., \& Krousgrill, C. (2008). Distance Education: New Technologies and New Directions. Proceedings of the IEEE, 96(6), 917-930. https://doi.org/10.1109/JPROC.2008.921612

İşman, A. (2011). Uzaktan Eğitim. Ankara: Pegem Academy Publishing.

Johnson, B. \& Turner, L. A. (2003). Data collection strategies in mixed methods research. In A. Tashakkori, \& C. Teddlie (Eds.), Handbook of mixed methods in social and behavioral research (pp. 297-319). Los Angeles: SAGE Publishing.

Karakaya, M., \& Aksoy, H. H. (2005). Uzaktan Eğitim Yüksek Lisans Çalışması. Ankara: Ankara University Faculty of Education Publishing.

Karakuş, N., Ucuzsatar, N., Karacaoğlu, M. Ö., Esendemir, N., \& Bayraktar, D. (2020). Türkçe Öğretmeni Adaylarının Uzaktan Eğitime Yönelik Görüşleri. RumeliDe Dil ve Edebiyat Araştırmaları Dergisi, 19, 220-241. https://doi.org/10.29000/rumelide.752297

Karatepe, F., Küçükgençay, N., \& Peker, B. (2020). Öğretmen Adayları Senkron Uzaktan Eğitime Nasıl Bakıyor? Bir Anket Çalışması. Uluslararası Sosyal ve Beşeri Bilimler Araştırma Dergisi, 7(53), 1262-1274. http://dx.doi.org/10.26450/jshsr.1868

Moçoşoğlu, B. \& Kaya, A. (2020). Koronavirüs Hastalığı (COVID-19) Sebebiyle Uygulanan Uzaktan Eğitime Yönelik Öğretmen Tutumlarının İncelenmesi. Kahramanmaraş̧ Sütçü İmam Üniversitesi Eğitim Dergisi, 2(1), 15-43.

Moore, M. G., \& Diehl, W. C. (2003). Handbook of Distance Education. London: Lawrence Erlbaum Associates Publishers.

Moore, M. G., \& Kearsley, G. (2005). Distance Education: A System View. Canada: Wadsworth Publication.

Odabaş, H. (2003). İnternet Tabanlı Uzaktan Eğitim ve Bilgi ve Belge Yönetimi. Türk Kütüphaneciliği, 17(1), 22-36.

Simonson, M., Smaldino, S. E., Albright, M., \& Zvacek, S. (2012). Teaching and Learning at a Distance: Foundations of Distance Education. Boston: Pearson Education.

Toker-Gökçe, A. (2008). Küreselleşme Sürecinde Uzaktan Eğitim. Dicle Üniversitesi Ziya Gökalp Eğitim Fakültesi Dergisi, 11, 1-12.

Traxler, J. (2018). Distance Learning-Predictions and Possibilities. Education Sciences, 8(35), 1-13. https://doi.org/10.3390/educsci8010035

United Nations Educational Scientific and Cultural Organization. (2021). UNESCO. Retrieved from https://en.unesco.org/covid19/educationresponse\#schoolclosures

Uşun, S. (2006). Uzaktan Eğitim. Ankara: Nobel Academic Publishing.

Ülkü, S. (2018). Illkokullarda görev yapan öğretmenlerin uzaktan eğitime yönelik tutumları (Unpublished master's dissertation). Abant İzzet Baysal University, Bolu, Turkey.

World Health Organization. (2020). World Health Organization. Haziran 14, 2021 tarihinde World Health Organization Retrieved from https://www.who.int/emergencies/diseases/novel-coronavirus-2019/ coronavirus-disease-answers?query=What $+\mathrm{is}+\mathrm{COVID} 19 \% 3 \mathrm{~F} \&$ referrerPageUrl=https $\% 3 \mathrm{~A} \% 2 \mathrm{~F} \% 2 \mathrm{Fwww} . \mathrm{w}$ 
ho.int $\% 2 \mathrm{Femergencies} \% 2 \mathrm{Fdiseases} \% 2 \mathrm{Fnovel}$-coronavirus-2019\%2Fcoronavirus-disease-answers

Yenilmez, K., Balbăg, M. Z., \& Turgut, M. (2017). Öğretmen adaylarının uzaktan eğitime yönelik tutumlarının bazı değişkenler açısından incelenmesi. Erzincan Üniversitesi Eğitim Fakültesi Dergisi, 19(2), 91-107. https://doi.org/10.17556/erziefd.305902

\section{Note}

Note 1. We emailed Mrs. Ağır on 24.03.2021 to obtain his permission to use the Distance Learning Attitude Scale (DLAS) for our research. Mrs. Ağır replied back on 25.03.2021 allowing us to use the scale.

\section{Copyrights}

Copyright for this article is retained by the author(s), with first publication rights granted to the journal.

This is an open-access article distributed under the terms and conditions of the Creative Commons Attribution license (http://creativecommons.org/licenses/by/4.0/). 